\title{
SENIOR SYNONYMS OF PTYCHODUS LATISSIMUS AGASSIZ, 1835 AND PTYCHODUS MAMMILLARIS AGASSIZ, 1835 (ELASMOBRANCHII) BASED ON TEETH FROM THE BOHEMIAN CRETACEOUS BASIN (THE CZECH REPUBLIC)
}

\author{
ARNAUD BRIGNON \\ 5 villa Jeanne d'Arc, 92340 Bourg-la-Reine, France; e-mail: arnaud.brignon@yahoo.com
}

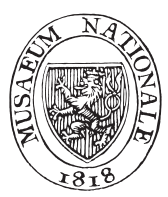

Brignon, A. (2015): Senior synonyms of Ptychodus latissimus Agassiz, 1835 and Ptychodus mammillaris AgAssiz, 1835 (Elasmobranchii) based on teeth from the Bohemian Cretaceous Basin (the Czech Republic). - Acta Mus. Nat. Pragae, Ser. B Hist. Nat., 71(1-2): 5-14. Praha. ISSN 1804-6479.

\begin{abstract}
Teeth of the genus Ptychodus (Elasmobranchii, Ptychodontidae) from the Bohemian Cretaceous basin (the Czech Republic) were first reported by Kašpar Maria von Sternberg in the 1820 s. These specimens were kept at that time in the "Wlastenské Museum w Čechách" (= Patriotic Museum in Bohemia). During the summer of 1833, Louis Agassiz carried out an inventory of the "fossil fishes" in this museum. In a summary of this work, published in 1834, the name Ptychodus schlotheimii was introduced for the first time. Unambiguously referring to a figure of a "fish tooth" published by von Sternberg in 1827, Ptychodus schlotheimii AGASsIz, 1834 is shown to be a senior synonym of Ptychodus latissimus AGAssiz, 1835. Conditions exist, however, which allow reversal of precedence as stated in Article 23.9.1 of the International Code of Zoological Nomenclature. Thus, Ptychodus latissimus is regarded as valid, qualifying as a nomen protectum, whereas Ptychodus schlotheimii AGASSIZ, 1834 is invalid, qualifying as nomen oblitum. It can also be shown that Buffonites undulatus STERNBERG, 1829 and Buffonites knorrii STERnBerg, 1829 are senior synonyms of Ptychodus mammillaris AGASSIZ, 1835. In this case also reversal of precedence can be applied and Ptychodus mammillaris is qualified as nomen protectum, whereas Buffonites undulatus and Buffonites knorrii are qualified as nomina oblita. The nomenclatural acts presented in this article for preserving taxonomic stability allow to maintain Ptychodus mammillaris as the type species of the genus Ptychodus Agassiz, 1835.
\end{abstract}

Ptychodus, Ptychodontidae, Chondrichthyes, Late Cretaceous, the Czech Republic, Bohemia, Louis Agassiz, Kašpar Maria von Sternberg, reversal of precedence.

Received October 17, 2014

Issued October, 2015

\section{Introduction}

Ptychodus is a durophagous shark genus (Elasmobranchii, Ptychodontidae) which occurs in Albian-Campanian marine deposits of Europe, North and South America, Asia, northern and western Africa (Cappetta 2012). The genus is known primarily by its teeth, which are characterized by a thick crown suited for crushing or grinding shelled macroinvertebrates. Teeth in Ptychodus are arranged in parallel rows closely juxtaposed, forming a pavement-like dentition. One of the first references to Ptychodus teeth can be found as early as the beginning of the $18^{\text {th }}$ century. In the posthumously published catalogue of the palaeontological collection of the English naturalist, antiquarian and geologist John Woodward (1665-1728), a Ptychodus tooth was described as follows: "Part of a large hard, boney Substance, seeming to have been the Palate of some Fish, having its outer Surface ridged and furrow'd alternately. The ridges are sharp, except in the middle, and upper part, where it has been most expos'd to be fretted and worn in breaking the Shells of the Creature lived on. [...]. Found near 40 Foot deep in the great Chalk-pit at Greenhithe" (J. Woodward 1729: part $2,85)$. Interestingly, Woodward correctly interpreted this "ridged palate" as belonging to a durophagous fish. The quarries at Greenhithe in Kent exploited Santonian chalk (Micraster coranguinum zone) where Ptychodus remains are commonly found (A. S. Woodward 1912: 232). John Woodward owned other Ptychodus teeth discovered in the Chalk at "Rygate" (Reigate) near Banstead and at "Smitham Bottom" near Croydon in Surrey (J. Woodward 1729: part 2, catalogue numbers n.100-n.103, n.103x, n.103†, n. 103†). One of the first illustrations of a Ptychodus tooth appears in a publication by the German mineralogist Franz Ernst Brückmann (1697-1753) back in 1737 (Brückmann 1737). In a paper published in 1752, he attributed these teeth to bony fishes allied to diodons or porcupinefishes (Teleostei, Tetraodontiformes) (Brückmann 1752). Since then, this conclusion was widely accepted in the literature until the beginning of the 1830s (Knorr and Walch 1769: 235, 1775: 209, Catullo 1820, Mantell 1822: 231). These teeth were also referred to as "Bufonites à dos silloné" in French (Bufonites with wrinkled back) or "Bufoniten mit gefurchtem Rücken" in German. The German palaeontologist Ernst Friedrich von Schlotheim (1764-1832) appears to have been the first to unambiguously attribute them to cartilaginous fishes allied to rays (Schlotheim 1822: 70) even though this hypothesis was also formulated by some others before him (Catullo 1820: 390, Defrance 1821: 70-71). Louis Agassiz described them as crushing teeth of "Placoid fishes". This obsolete term essentially corresponds to Chondrichthyes although Agassiz also placed the genus Ceratodus (Sarcopterygii, Dipnoi, Ceratodontimorpha) and Petromyzontida (Agnatha) in 
"Placoids" (Gaudant 1980). The systematic position of Ptychodontidae within Chondrichthyes still remains a puzzling question. The different hypotheses and points of view are summarized for instance by Shimada et al. (2009) and Cappetta (2012). Often assigned to Hybodontoidea based on the primitive structure of the teeth, this family is alternatively placed within Neoselachii by some authors (Stewart 1980, Hamm 2008) owing to the occurrence of calcified centra discovered on well preserved Ptychodus specimens.

Bibliographic research on Ptychodus sharks led to the rediscovery of several Czech papers that went virtually unnoticed since their publication in the 1820 s and the 1830 s. Senior synonyms of Ptychodus latissimus AgAssiz, 1835 and the type species Ptychodus mammillaris AgAssiz, 1835 have been rediscovered. These synonyms are based on specimens that were kept at that time in the National Museum in Prague. The historical context of these publications and the impact of these senior synonyms on nomenclature are discussed.

\section{Creation of the genus Ptychodus Agassiz: a historical overview}

Louis Agassiz's masterpiece "Recherches sur les poissons fossiles" in five volumes was published in installments ("Livraisons" in French) over a period of more than ten years between July 1833 and the beginning of 1844 (Brignon 2014: 250-252). Except for volume 1, each volume deals with a particular group of "fishes". Agassiz decided to publish small sections of text or plates from different volumes in each "Livraison" to avoid monotony. By doing so, he wanted to meet his subscribers' expectations by giving them the opportunity to get an idea about all the types of fossil fishes without waiting for completion of the book. This introduced in consequence great confusion. As evidenced by the "Avis aux lecteurs" (=Notice to Readers) printed on the wrappers of the Livraisons, Agassiz continually had to answer questions from his subscribers confused by the random publication of the plates and the different chapters. Even after completion of the book and up to now, there has always been some confusion about the creation dates of the numerous genus and species introduced for the first time in this book. This remark also applies to the genus Ptychodus with a date of creation set sometimes as 1835 (Welton and Farish 1993, Brito and Janvier 2002, Hamm 2008, Shimada et al. 2009, Carrillo-Briceño and Lucas 2013), 1838 (Radwanski and Marcinowski 1996, Underwood and Cumbaa 2010, Cappetta 2012) or 1839 (Mendiola 2004, Vullo and Arnaud 2009, Cuny 2013: 162, Guinot et al. 2013) based on the publication dates of either the plates or the text descriptions of Ptychodus species in Agassiz's work. In addition, in September 1837 Agassiz (1837: vol. 3, 57-59, pl. 10a) introduced four new species, Ptychodus spectabilis, Pt. gibberulus, Pt. arcuatus and $P t$. articulatus, for fin spines found in the Chalk of Lewes which were later shown to belong to pachycormid fishes (Actinopterygii, Pachycormidae) (Cope 1875: 244c, A. S. Woodward 1895: 400).

In the $2^{\text {nd }}\left(\right.$ Agassiz 1834c), $4^{\text {th }}\left(\right.$ Agassiz 1835a), $5^{\text {th }}$ (Agassiz 1835b), 6 ${ }^{\text {th }}$ (Agassiz 1836a), $7^{\text {th }}$ (Agassiz 1836b), $8^{\text {th }} \& 9^{\text {th }}\left(\right.$ Agassiz 1837), $11^{\text {th }}$ (Agassiz 1838), $10^{\text {th }} \& 12^{\text {th }}$
(Agassiz 1839a), 13 ${ }^{\text {th }}$ (Agassiz 1839b), 14 $4^{\text {th }}$ (Agassiz 1842), $15^{\text {th }} \& 16^{\text {th }}$ (Agassiz 1843) "Livraisons" of the "Recherches sur les poissons fossiles", Agassiz published 72 supplementary sheets entitled "Feuilleton additionnel" (Brignon 2014: 250-252). The "Feuilleton" was intended to give additional information to the five volumes. In 1843, Agassiz finally decided to include all the information contained in the "Feuilleton" within the five volumes. In a folio page entitled "avis aux relieurs" (advice to the binder), Agassiz recommended removal of the "Feuilleton" which, according to Agassiz, contained redundant information. As a consequence, the "Feuilleton" is absent in most copies of the book. For instance, the "Feuilleton" is missing in Agassiz's own personal copy which can be virtually considered as the reference copy (this copy is kept in the Ernst Mayr Library of the Museum of Comparative Zoology at Harvard University). A few rare copies, however, still contain surviving "Feuilleton". These remarks are not anecdotal as the "Feuilleton" contains the first occurrences of numerous new valid taxon names. The genus Ptychodus and the five species Pt. latissimus, Pt. polygyrus, Pt. mammillaris, Pt. decurrens and Pt. altior thus appeared in the "Feuilleton" published with the $4^{\text {th }}$ "Livraison" in January 1835 (Agassiz 1835a: Feuilleton additionnel, 54) (Table 1). Regarding the first four species, Agassiz referred to the figures published by Mantell in his "Fossils of the South Downs" (Mantell 1822: pl. 32, fig. 17-21, 23-25, 27, 29). Among these species, the first three (Pt. latissimus, Pt. polygyrus and Pt. mammillaris) are considered as valid (Hamm 2008, Cappetta 2012). 1835 must be undoubtedly regarded as the year of their creation since Agassiz clearly referred to published figures, thus fulfilling condition of article 12.2.7 of the International Code of Zoological Nomenclature (ICZN 1999). However, the species Ptychodus decurrens was not defined in 1835 because only the name is mentioned but without any description or reference to a figure. Ptychodus decurrens was validated later along with the $11^{\text {th }}$ "Livraison" published in November 1838 (Agassiz 1838: vol. 3, pl. 25b).

However, the genus Ptychodus was introduced earlier in a poorly known publication attributed to Louis Agassiz and dated 1834 (Agassiz 1834a: 69-70). In that paper, Agassiz enumerates fossil fishes from the "Wlastenské Museum w Čechách" or "Das vaterländische Museum in Böhmen" in German (= Patriotic Museum in Bohemia). This museum was founded in 1818 by Kašpar Maria von Sternberg (1761 1838) (Schweizer 2004). Agassiz visited the museum in the summer of 1833 during a trip to Germany (Agassiz 1834b). In this publication, Agassiz introduced for the first time the species Ptychodus mammillaris and Ptychodus decurrens without however giving any description, or figures. In this 1834 publication, these two species must be considered as nomina nuda. Agassiz also introduced the species "Ptychodus Schlottheimii" [sic]. Clearly named in honor of Ernst Friedrich von Schlotheim who figured a Ptychodus tooth in a book published in 1822 (Schlotheim 1822: 70, 94, pl. 13, fig. 2), the name can be corrected to Ptychodus schlotheimii under authority of article 32.5 of the International Code of Zoological Nomenclature (ICZN 1999). In the 1834 publication, this new name is accompanied by the following indication: "Fischzähne von Ptychodus Schlottheimii 
(abgebildet im Maiheft der Monatschrift der Gesellschaft des vaterländischen Museums, erster Jahrgang 1827)" which can be translated as "Fish teeth of Ptychodus Schlottheimii (figured in the May issue of Monatschrift der Gesellschaft des vaterländischen Museums, first year, 1827)". Indeed, in the issue of the journal mentioned by Agassiz, von Sternberg (1827a: 68, fig. 1) figured what he considered to be a fossil fish tooth (Text-fig. 1). Fulfilling the conditions of Articles 12.1 and 12.2.7 for names published before 1931, Ptychodus schlotheimii became an available name as from 1834 and its holotype by monotypy is the specimen figured in von Sternberg's paper published in 1827. The same figure was also published in the journal "Verhandlungen der Gesellschaft des vaterländischen Museums in Böhmen" (Sternberg 1827b: 21, fig. 1) which is an extract of the "Monatschrift", and the Czech version of the latter entitled "Časopis Společnosti wlastenského museum w Čechách" (= Journal of the Patriotic museum in Bohemia Society) (Sternberg 1827c: 26, fig. 1).

The holotype of Ptychodus schlotheimii Agassiz, 1834 was from Benátky nad Jizerou (Benatek in German) (Sternberg 1827a: 68), a town on the Jizera River in the Central Bohemian Region of the Czech Republic. The tooth comes from the silty marlstones or limestones of the Jizera formation (Middle - Upper Turonian), possibly from the beds where other Ptychodus and plesiosaurian teeth have been reported (Geinitz 1842, Reuss 1844: 256, Frič 1889: 66, Kear et al. 2014). The type specimen is square in outline with five widely spaced, thick, slightly curved, and sharp parallel transverse ridges. The marginal area is covered with coarse irregular granulations. The general shape is typical of a lateral file tooth of Ptychodus latissimus AGASSIZ, 1835 which thus appears to be a junior synonym of Ptychodus schlotheimii AgAssiz, 1834. The holotype of Ptychodus schlotheimii AgAssiz, 1834 was also figured by Geinitz (1842: pl. 17, fig. 3, 1850: pl. 17, fig. 3) under the name Ptychodus latissimus. Antonín Frič (1889: 66) also mentioned in 1889 that a tooth of Ptychodus latissimus from Benatek, belonging to the former von Sternberg's collection, was kept in Prague Museum. This seems to indicate that the holotype of Ptychodus schlotheimii was still present in this museum until at least the end of the nineteenth century. Unfortunately, in a recent investigation of the fossil vertebrate collection this specimen was not located (Boris Ekrt, National Museum, Prague, personal communication).

\section{Status of Ptychodus schlotheimii Agassiz, 1834}

The name Ptychodus schlotheimii was used by Geinitz (1842: 63-64, 1850: 63-64) in his "Charakteristik der Schichten und Petrefacten des Sächsisch-böhmischen Kreidegebirges" to designate two teeth from the Cretaceous of Benatek (Benátky nad Jizerou) and Hundorf (Hudcov in Czech, a town near Teplice) in Bohemia. In the two editions of this book, Geinitz attributes this species to Agassiz but did not mention the 1834 publication in which the name appeared for the first time. Geinitz (1842: 63), as well as Reuss (1844: 256), first considered Ptychodus schlotheimii and Ptychodus latissimus as two distinct species. However, he identified the holotype of Ptychodus schlotheimii (Text-fig. 1; Geinitz

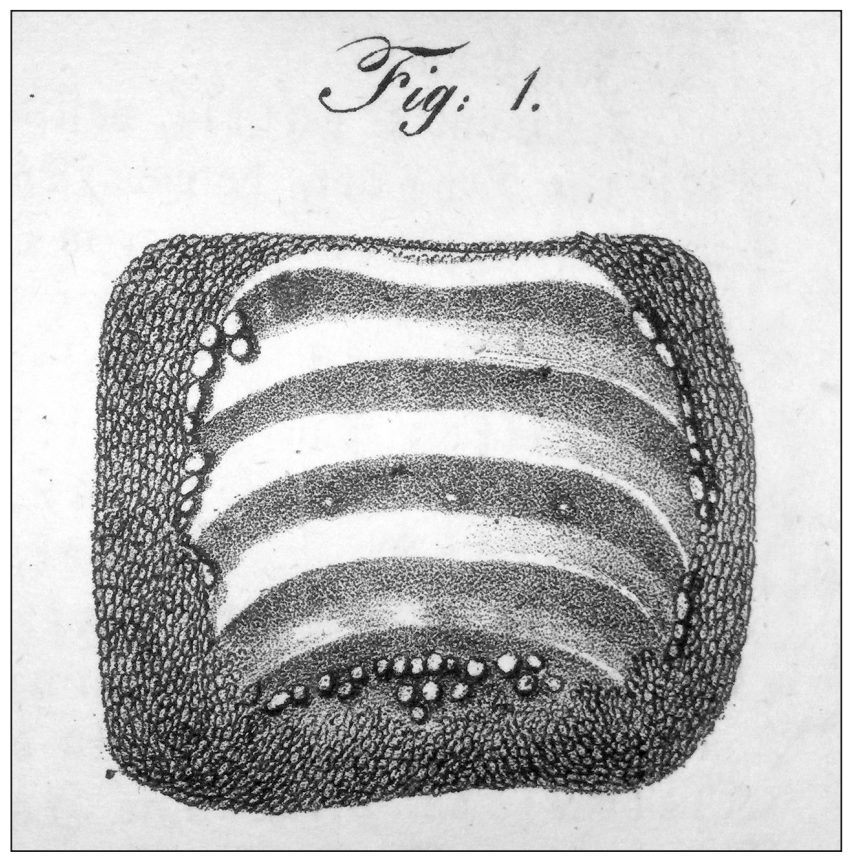

Text-fig. 1. Occlusal view of a "fish tooth" from Benátky nad Jizerou (the Czech Republic) published by Kašpar Maria von Sternberg (1827a-c) upon which Ptychodus schlotheimii AGASSIZ, 1834 was created. The figure of the specimen in the original plate has a width of $39 \mathrm{~mm}$.

1842: pl. 17, fig. 3) as belonging to Ptychodus latissimus. As a consequence, Ptychodus schlotheimii sensu Geinitz must be regarded as an attempt to define a separate species from the homonym created by Agassiz in 1834. Geinitz (1849: 88, 1875: 212) and Reuss (1845: 1) finally concluded that Ptychodus schlotheimii and Ptychodus latissimus were synonyms and gave priority to Ptychodus latissimus. In his "Fauna der Vorwelt", Giebel (1848: 334) mentioned the name Ptychodus schlotheimii. Though he clearly indicates Agassiz's 1834 publication for the creation of this species, he considered it as a synonym of Ptychodus latissimus giving precedence to the latter, more recent species, without any explanation. The same conclusion was followed by Bronn (1848: 1058-1059), Kiprijanoff (1852) and Fritsch (1878: $15)$. Not being aware that the Agassiz's 1834 publication established the creation of Ptychodus schlotheimii, most of the authors then attributed Ptychodus schlotheimii to Geinitz (Liebus 1902, Fossa-Mancini 1921, Herman 1977: 67) or occasionally to Reuss (Bayer 1905). Thinking that Ptychodus schlotheimii was created by Geinitz in the second edition of his "Charakteristik der Schichten und Petrefacten" (Geinitz 1850), this species name has been considered as a junior synonym of Ptychodus latissimus AgAssiz, 1835 by a large majority of authors (A. S. Woodward 1889: 147, Dacqué 1939: 197, Herman 1977, Hamm 2008). The 1834 publication by Louis Agassiz clearly gives evidence to the contrary.

Why Agassiz himself did not use Ptychodus schlotheimii in his "Recherches sur les poissons fossiles"? The answer can be found in a publication published in 1844. Agassiz considered Ptychodus schlotheimii and Ptychodus latissimus as synonyms, but as he indicated (Agassiz 1844: 204), the epithet "schlotheimii" was certainly suggested by the German 
palaeontologist Georg Graf zu Münster (1776-1844). Indeed, Münster used to send manuscript notes on fossil fishes along with drawings to his Swiss colleague (Agassiz 1835a: Feuilleton additionnel, 57, 1836b: Feuilleton additionnel, 97, 1838: Feuilleton additionnel, 107-108, Surdez 1974). Agassiz probably used the name Ptychodus schlotheimii in the manuscript notes that he wrote during the inventory of the Prague Museum collections in the summer of 1833, having it in mind to change this name later as the epithet "schlotheimii" was not his choice. A plausible hypothesis is that in 1834 von Sternberg then published the manuscript notes given to him by Agassiz in the "Verhandlungen der Gesellschaft des vaterländischen Museums in Böhmen". This is confirmed by another version of this paper published in the 1835 issue of "Neues Jahrbuch für Mineralogie, Geognosie, Geologie und Petrefaktenkunde" where it is clearly stated that the paper was communicated by von Sternberg (1835). Agassiz often complained about the fact that some of his provisional names were sometimes published by his friends and colleagues (Agassiz 1833: vol. 2, 4, footnote).

Replacing the name Ptychodus latissimus AgAssiz, 1835 with Ptychodus schlotheimii AgAssiz, 1834 is not in the interest of nomenclatural stability. To mediate the Principle of Priority, Article 23.9.1 of the International Code of Zoological Nomenclature (ICZN 1999) allows for a reversal of precedence of a junior synonym when the senior synonym has not been used as a valid name after 1899 (Article 23.9.1.1) and the junior synonym "has been used for a particular taxon, as its presumed valid name, in at least 25 works, published by at least 10 authors in the immediately preceding 50 years and encompassing a span of not less than 10 years" (Article 23.9.1.2).

In only one paper published after 1899, the name Ptychodus schlotheimii is not synonymized with Ptychodus latissimus. It appears in a list referencing all the species of Ptychodus created so far without any discussion on their respective validity (Fossa-Mancini 1921: 209). The name is attributed to "GEINITZ, 1850" thus referring to the second edition of Geinitz's "Charakteristik der Schichten". Given that Geinitz misused the name Ptychodus schlotheimii attributing Agassiz's holotype of this species (Text-fig. 1; Geinitz 1842, 1850: pl. 17, fig. 3) to Ptychodus latissimus, the single allusion to the name "Ptychodus schlotheimii GeINITZ, 1850" by Fossa-Mancini did not constitute a valid use of Ptychodus schlotheimii AgAssiz. The same conclusion can be drawn from different papers in which the epithet "schlotheimi [sic] GeINITZ" was also used to designate a variety or a subspecies of Ptychodus latissimus (Liebus 1902, Matějka and Roth 1949: 304, Hanzlíková and Roth 1963: 68, Krajewski and Urbaniak 1964: 101, 226, 229, Hanzlíková 1972: 14). Thus, the name Ptychodus schlotheimii AGAssiz, 1834 can not be considered to have been used as a valid name for the taxon it denotes since 1899 (thus fulfilling Article 23.9.1.1 of the Code). In Appendix 1, 26 publications are listed in which the name Ptychodus latissimus AGASSIZ was used as a valid name, thus fulfilling Article 23.9.1.2 of the Code. As both requirements of Article 23.9.1 are met, and in accordance with Article 23.9.2, the name Ptychodus latissimus AgAssiz, 1835 is considered a valid name and takes precedence over Ptychodus schlotheimii AgAssiz, 1834. Ptychodus latissimus AGASsIZ,

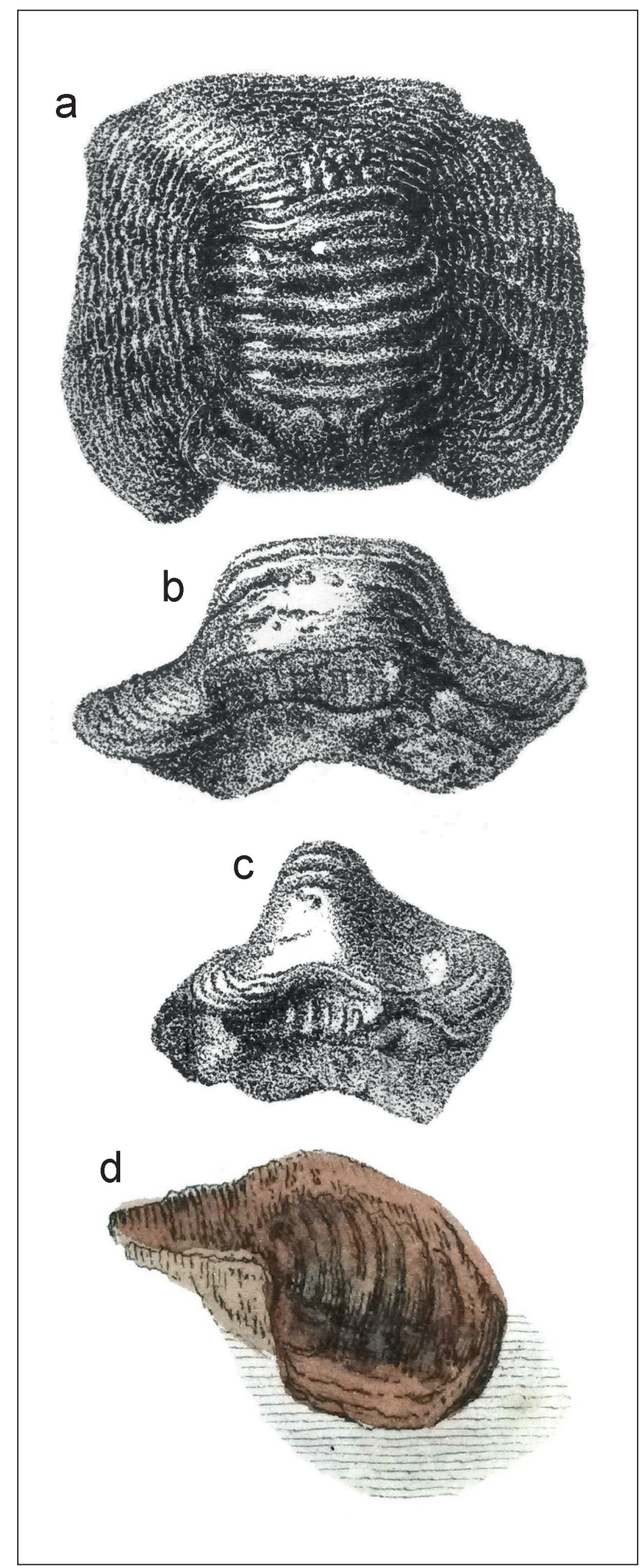

Text-fig. 2. a-b, figures published by von Sternberg (1829a-c: fig. 4a, b) showing a tooth of Buffonites undulatus from Lysá nad Labem (the Czech Republic). a, occlusal view. b, posterior view. In the original plate, these figures have a width of $26 \mathrm{~mm}$. c-d, Buffonites knorrii STERNBERG, 1829. c, figure published by von Sternberg (1829a-c: fig. 5) showing a tooth from Lysá nad Labem. In the original plate, this figure has a width of $18 \mathrm{~mm}$. d, figure published by Knorr and Walch (1769: pl. H.I.a, fig. 5, 1775: pl. H.I.a, fig. 5) showing a tooth from Quedlinburg, Saxonia-Anhalt, Germany. In the original plate, this figure has a width of $18 \mathrm{~mm}$. 
1835 now becomes nomen protectum and Ptychodus schlotheimii AGASSIZ, 1834, nomen oblitum.

\section{The genus Buffonites Sternberg, 1829}

In 1829 Kašpar Maria von Sternberg established the names Buffonites undulatus and Buffonites knorrii for teeth belonging to the genus Ptychodus (Sternberg 1829a-c). As a vernacular name, "Bufonites" (or Buffonites) was often used to designate various types of fossil actinopterygian teeth during the eighteenth century and up to the beginning of the nineteenth century. However, the German and Czech versions of Sternberg's publication are printed in Gothic characters except for Buffonites undulatus and Buffonites knorrii which are printed in Latin script. In the context of this publication, these two Latinized binomial names are associated with illustrations. Fulfilling the requirements of Articles 11 and 12.2.7, they can be thus considered as available names. The figures given by von Sternberg (Text-fig. $2 \mathrm{a}-\mathrm{c}$ ) represent two teeth from the Plänerkalk of Lysá nad Labem (Lissa an der Elbe in German), most probably found in the Middle Turonian calcareous siltstones with limestone horizons of the Jizera Formation (Kear et al. 2014). They were also figured by Geinitz (1842: pl. 17, fig. 7, 9, 1850: pl. 17, fig. 7, 9) and were kept at that time in Prague Museum. These specimens have not been located although one other specimen from Lysá nad Labem figured by Fritsch (1878: 14, fig. 33) under the name Ptychodus mammillaris is still preserved in this Museum (Boris Ekrt, personal communication).

The tooth assigned to Buffonites undulatus STERNBERG, 1829 (Text-fig. 2a-b) has a moderately high and knob like crown. Eight parallel and clearly delineated transverse ridges cover the apex. The tooth has a wide marginal area covered with coarse, granular and concentric ornamentation. It clearly represents a medial tooth of Ptychodus mammillaris which thus appears to be a junior synonym of Buffonites undulatus. The second tooth assigned to Buffonites knorrii by von Sternberg $(1829 \mathrm{a}-\mathrm{c})$ also has a moderately high and knob like crown (Text-fig. 2c). The apex is rounded and has a reduced width in comparison with the Buffonites undulates specimen. Parallel ridges are visible. It corresponds to a lateral or posterior tooth of Ptychodus mammillaris. Von Sternberg also assigned to Buffonites knorrii a specimen from the Late Cretaceous of Quedlinburg, Saxonia-Anhalt, Germany, figured by Knorr and Walch (1769: pl. H.I.a, fig. 5, 1775: pl. H.I.a, fig. 5) (Text-fig. 2d). Despite the poor quality of this figure, the tooth most likely belongs to Ptychodus mammillaris.

All the conditions are met which allow a reversal of precedence as provided by Article 23.9.1 of the ICZN. Buffonites knorrii STERnBERG, 1829 was mentioned by a few authors (Agassiz 1839a: vol.3, 153, Reuss 1845: 2, Bronn 1848: 1058-1059) but both this species and Buffonites undulatus SternBERG, 1829 were not used as valid since 1899 (condition 23.9.1.1). Secondly, Ptychodus mammillaris has been used as a valid name in at least 25 publications (see Appendix 2), published by at least 10 authors during the past 50 years and encompassing a span of not less than 10 years (condition 23.9.1.2). Thus, Ptychodus mammillaris AgAssiz, 1835 is regarded as valid, qualifying as a nomen protectum, whereas the names Buffonites undulatus STERNBERG, 1829 and Buffonites knorrii STERNBERG, 1829 are recognized as invalid, qualifying as nomina oblita.

\section{Acknowledgements}

I am deeply indebted to Boris Ekrt for providing me with information on the palaeontological collections of the National Museum (Prague), photographs of specimens and translation of papers in Czech. I thank Dan Pemberton (Sedgwick Museum of Earth Sciences, University of Cambridge) for providing information on specimens in the Woodwardian Museum. This paper benefited from comments by Martin Mazuch and an anonymous reviewer.

\section{References}

Adnet, S., Cappetta, H., Mertiniene, R. (2008): Re-evaluation of squaloid shark records from the Albian and Cenomanian of Lithuania. - Cretaceous Research, 29: 711-722. http://dx.doi.org/10.1016/j.cretres.2008.01.014

Agassiz, J.-L.-R. (1833): Recherches sur les poissons fossiles, $1^{\text {st }}$ livraison (July 1833). - Petitpierre et Prince (text) and H. Nicolet (plates), Neuchâtel, vol. 1, [i]-xii, [1]-16, pl. A, B, C, D, E, F, G; vol. 2, [1]-48, pl. A, B, C, $1,2,3,4,5,6,7$; vol. 4, 17-32, pl. A, 1, 2; vol. 5, $1^{\text {st }}$ part, 17-24, pl. A, 1, 2.

Agassiz, J.-L.-R. (1834a): Verzeichniss der in der Peträfakten-Sammlung des vaterländischen Museums befindlichen versteinerten Fische. - Verhandlungen der Gesellschaft des Vaterländischen Museums in Böhmen, 12: 66-71.

Agassiz, J.-L.-R. (1834b): Recherches sur les poissons fossiles [prospectus]. - A. Richter, London, janvier 1834, $16 \mathrm{pp}$.

Agassiz, J.-L.-R. (1834c): Recherches sur les poissons fossiles, $2^{\text {nd }}$ livraison (February 1834). - Petitpierre et Prince (text) and H. Nicolet (plates), Neuchâtel, vol. 1, 17-40; vol. 2, 49-84, pl. F, 11, 12, 15, 16, 22, 26, 27, 28, $29,30,32,33,40$; vol. 4 , pl. 3, 4, 5, 6; vol. 5, $1^{\text {st }}$ part, 25-32, pl. 3, 4, 5, 6; Feuilleton additionnel, [1]-20; liste des souscripteurs, [1]-2.

Agassiz, J.-L.-R. (1835a): Recherches sur les poissons fossiles, $4^{\text {th }}$ livraison (January 1835). - Petitpierre et Prince (text) and H. Nicolet (plates), Neuchâtel, vol. 2, pl. 49, 54, 55, 60; vol. 3, pl. D, 46; vol. 4, 33-52, pl. 23, 38; vol. 5, pl. F, 11a, 20, 24, 50, 51, 54-59; Feuilleton additionnel, 21-64; liste des souscripteurs, [3]-5.

Agassiz, J.-L.-R. (1835b): Recherches sur les poissons fossiles, $5^{\text {th }}$ livraison (June 1835). - Petitpierre et Prince (text) and H. Nicolet (plates), Neuchâtel, vol. 2, [i]-[iv], 85-200, pl. 21, 23, 25c, 30a, 30b, 30c, 35, 65; vol. 3, pl. E, F, G, H, 26, 27, 28, 29; vol. 4, pl. J, 37, 40, 42, 43; vol. 5, pl. L, 14, 19, 23, 25, 27, 52; Feuilleton additionnel, $65-74$

Agassiz, J.-L.-R. (1836a): Recherches sur les poissons fossiles, $6^{\text {th }}$ livraison (March 1836). - Petitpierre (text) and H. Nicolet (plates), Neuchâtel, vol. 2, 201-224, pl. D, 1c, 1d, 1e, 2b, 2c, 2d, 4b, 4c, 8, 10, 10a, 10c, 14b, 14c, 23d, 25, 25a, 25b, 25d, 25e; vol. 4, 53-108; Feuilleton additionnel, 75-86.

Agassiz, J.-L.-R. (1836b): Recherches sur les poissons fossiles, $7^{\text {th }}$ livraison (June-July 1836). - Petitpierre (text) and H. Nicolet (plates), Neuchâtel, vol. 2, pl. 2a, 10b, 14a, 
21a, 26a, 29a; vol. 3, pl. 2-8, 10-12, 41-44; Feuilleton additionnel, 87-98.

Agassiz, J.-L.-R. (1837): Recherches sur les poissons fossiles, $8^{\text {th }}$ and $9^{\text {th }}$ livraisons (September 1837). Petitpierre (text) and H. Nicolet (plates), Neuchâtel, vol. 2, 225-264, pl. 1a, 1b, 39, 48, 65a bis, 65b, 65c, 65d, 66a; vol. 3, [i]-viii, 1-[72], pl. B, C, 10a, 10b, 13, 14, 16, 21, 25a, 40a; vol. 4, pl. C, D, F, H, K, L, 8, 9, 11a, 13, 14a-e; vol. 5, pl. D, G, 25a-c, 60a-c; Feuilleton additionnel, 99-106.

Agassiz, J.-L.-R. (1838): Recherches sur les poissons fossiles, $11^{\text {th }}$ livraison (November 1838). - Petitpierre (text) and H. Nicolet (plates), Neuchâtel, vol. 2, pl. 42, 43; vol. 3, [73]-140, pl. 1a, 8a, 8b, 15, 17, 19, 20, 24, 25b, 30-35, 39, 40; vol. 5, pl. 60; Feuilleton additionnel, 107-116.

Agassiz, J.-L.-R. (1839a): Recherches sur les poissons fossiles, $10^{\text {th }}$ and $12^{\text {th }}$ livraisons (April 1839). - Petitpierre (text) and H. Nicolet (plates), Neuchâtel, vol. 2, pl. 23d (bis), 33b, 41, 50-53, 53a, 56-58, 58a, 59, 61, 61a, 62-64, 66-69, 69a, 70-72, 72a, 73, 74; vol. 3, 141-156, pl. 9, 23, 25, 30a; vol. 4, [i]-xvi, 1-16, 16*- [16**]; vol. $5,2^{\text {nd }}$ part, [1]-56, pl. 38-42, 49, 53, 60d; Feuilleton additionnel, 117-126.

Agassiz, J.-L.-R. (1839b): Recherches sur les poissons fossiles, $13^{\text {th }}$ livraison (November 1839). - Petitpierre (text) and H. Nicolet (plates), Neuchâtel, vol. 2, pl. 69b; vol. 4, 109-204, pl. 15, 16, 17, 26, 27, 28, 29, 30, 31, 32, $33,34,35,36,37 \mathrm{a}, 39,41,41 \mathrm{a}, 44$; vol. 5, pl. 15, 26, 30, 31, 43, 61; Feuilleton additionnel, 127-130.

Agassiz, J.-L.-R. (1842): Recherches sur les poissons fossiles, $14^{\text {th }}$ livraison. - Jent et Gassmann, Soleure (text) and H. Nicolet, Neuchâtel (plates), vol. 2, pl. 45, 46, 47, 51a, 56a, 57a, 57b, 59a, 69c, 75; vol. 4, 205-291, 1-22; vol. 5, pl. 16, 17, 18, 21, 21a, 22, 32, 33, 34, 34a, 35, 36, 37, 37a, 62, 63, 64; Feuilleton additionnel, 131-138.

Agassiz, J.-L.-R. (1843): Recherches sur les poissons fossiles, $15^{\text {th }}$ and $16^{\text {th }}$ livraisons. - Jent et Gassmann, Soleure (text) and H. Nicolet, Neuchâtel (plates), vol. 2, $2^{\text {nd }}$ part, [1]-72, pl. B', B”, Ca, G, 23b, 23c, 31, 33a, 36-38, 42a, 44; vol. $3,157-390,382 *-382 * *, 1-32$, [33]-[34], pl. 1, 18, 22, $22 \mathrm{a}-\mathrm{b}, 26 \mathrm{a}, 38,40 \mathrm{~b}-\mathrm{d}, 45,47$; vol. 4 , pl. $23 \mathrm{~b}$; vol. $5,2^{\text {nd }}$ part, 57-84, pl. B, C, E, H, J, K, 9, 10, 28, 29, 37b, 44-48; Feuilleton additionnel, 139-144.

Agassiz, J.-L.-R. (1844): Synoptical table of British fossil fishes, arranged in the order of the geological formations. - Report of the British Association for the Advancement of Science, London, $13^{\text {th }}$ meeting, Cork, 1843: 194-207.

Albright, L. B., Gillette, D. D., Titus, A. L. (2013): Fossil vertebrates from the Tropic Shale (Upper Cretaceous), Southern Utah. - In: Titus, A. L., Loewen, M. A. (eds), At the top of the Grand Staircase: the Late Cretaceous of Southern Utah, Indiana University Press, Bloomington and Indianapolis, p. 536-562.

Antunes, M. T., Cappetta, H. (2002): Sélaciens du Crétacé (Albien-Maastrichtien) d'Angola. - Palaeontographica, Section A, 264: 85-146.

Bayer, F. (1905): Katalog českých fossilních obratlovců (Fossilia vertebrata Bohemiae). - Česká Akademie císaře Františka Josefa pro vědy, slovesnost a umění, Praha, 102 pp.
Becker, M. A., Wellner, R. W., Mallery, C. S. Jr., Chamberlain, J. A. Jr. (2010): Chondrichtyans from the Lower Ferron Sandstone Member of the Mancos Shale (upper Cretaceous: Middle Turonian) of Emery and Carbon Counties, Utah, USA. - Journal of Paleontology, 84: 248-266. http://dx.doi.org/10.1666/09-053R.1

Bendix-Almgreen, S. E. (1983): Carcharodon megalodon from the Upper Miocene of Denmark, with comments on elasmobranch tooth enameloid: coronoïn. - Bulletin of the Geological Society of Denmark, 32: 1-32.

Brignon, A. (2014): Les recherches paléoichthyologiques et géologiques sur le gisement permien de Muse près d'Autun (Saône-et-Loire) au début du XIXe siècle. Bulletin de la Société Géologique de France, 185: 233-252. http://dx.doi.org/10.2113/gssgfbull.185.4.233

Brito, P. M., Janvier, P. (2002): A ptychodontid (Chondrichthyes, Elasmobranchii) from the Upper Cretaceous of South America. - Geodiversitas, 24: 785-790.

Bronn, H. G. (1848): Index palaeontologicus oder Übersicht der bis jetzt bekannten fossilen Organismen, Erste Abtheilung, Zweite Hälfte (N-Z). - E. Schweizerbart, Stuttgart, pp. [i]-[ii] + 777-[1382].

Brückmann, F. E. (1737): Epistola itineraria LXIV. De lapidibus figuratis quibusdam rarioribus, nondum descriptis et delineatis, musei autoris. - Wolfenbüttel, 15 pp., 5 pls.

Brückmann, F. E. (1752): Petrefactum singulare \& curiosum, dentem seu palatum piscis ostracionis referens. - Acta Physico-Medica Academiae Caesareae LeopoldinoCarolinae Naturae Curiosorum, Norimbergae, 9: 116120, pl. 5, fig. 3-4; pl. 6, fig. 1-3.

Cappetta, H. (2012): Chondrichthyes. Mesozoic and Cenozoic Elasmobranchii: teeth. Handbook of Paleoichthyology, volume 3E. - Verlag Dr. Friedrich Pfeil, München, 512 pp.

Cappetta, H., Case, G. R. (1999): Additions aux faunes de sélaciens du Crétacé du Texas (Albien supérieurCampanien). - Palaeo Ichthyologica, 9: 5-111.

Carrillo-Briceño, J. D., Lucas, S. G. (2013): The first tooth set of Ptychodus atcoensis (Elasmobranchii: Ptychodontidae), from the Cretaceous of Venezuela. - Swiss Journal of Palaeontology, 132: 69-75. http://dx.doi.org/10.1007/s13358-013-0053-3

Catullo, T. A. (1820): Fine dell'Appendice alla memoria orittografica sopra gli avanzi marini che si trovano dentro i monti della Provincia Veronese. - Giornale di Fisica, Chimica, Storia Naturale, Medicina ed Arti, decade 2, 3 : 383-391, pl. 7-8.

Coggi, L. (1964): Dente di Ptychodus latissimus Ag. nella scaglia cretacica delle Madonie orientali (Sicilia centro-settentrionale). - Atti della Società Italiana di Scienze Naturali e del Museo Civico di Storia Naturale in Milano, 103(2): 118-128.

Cope, E. D. (1875): The Vertebrata of Cretaceous formations of the West. - Report of the United States Geological Survey of the Territories, Government Printing Office, Washington D. C., 2: i-iv, 1-303, 57 pl.

Cuny, G. (2013): Requins de la préhistoire à nos jours. Editions Belin, Paris, 224 pp. 
Dacqué, E. (1939): Die Fauna der Regensburg-Kelheimer Oberkreide. - Abhandlungen der Bayerischen Akademie der Wissenschaften, Mathematisch-naturwissenschaftliche Abteilung, Neue Folge, 45: 1-218, 17 pls.

Dean, D. R. (1998): Gideon Algernon Mantell. A bibliography with supplementary essays. - Scholars' Facsimiles \& Reprints Delmar, New York, 279 pp.

Defrance, J.-L.-M. (1821): Glossopètres (Foss.). - In: Dictionnaire des Sciences Naturelles, tome 19 (GLAGRZ), Levrault, Strasbourg et Paris, p. 65-73.

Diedrich, C. G. (2013): Facies related phylostratigraphy of the benthic neoselachian Ptychodus from the Late Cretaceous (Cenomanian/Turonian) of the Pre-North Sea Basin of Europe. - Cretaceous Research, 41: 17-30. http://dx.doi.org/10.1016/j.cretres.2012.10.007

Ekrt, B., Košt'ák, M., Mazuch, M., Voigt, S., Wiese, F. (2004): New records of teleosts from the Late Turonian (Late Cretaceous) of the Bohemian Cretaceous Basin (Czech Republic). - Cretaceous Research, 29: 659-673. http://dx.doi.org/10.1016/j.cretres.2008.01.013

Everhart, M. J. (2013): “The Palate Bones of a Fish?" - The first specimen of Ptychodus mortoni (Chondrichthyes; Elasmobranchii) from Alabama. - Bulletin of the Alabama Museum of Natural History, 31: 98-104.

Everhart, M. J., Darnell, M. K. (2004): Occurrence of Ptychodus mammillaris (Elasmobranchii) in the Fairport Chalk Member of the Carlile Shale (Upper Cretaceous) of Ellis County, Kansas. - Transactions of the Kansas Academy of Science, 107: 126-130.

http://dx.doi.org/10.1660/0022-8443(2004)107[0126:OO PMEI]2.0.CO;2

Fossa-Mancini, E. (1921): Alcune considerazioni sulla morfologia e sulla dietologia degli Ptychodus. - Atti della Società Toscana di Scienze Naturali, 33: 194-212.

Frič, A. (1889): Studien im Gebiete der böhmischen Kreideformation. Palaeontologische Untersuchungen der einzelnen Schichten. IV. Die Teplitzer Schichten. Archiv für die naturwissenschaftliche Landesdurchforschung von Böhmen, 7(2): 1-120.

Fritsch [Frič in Czech], A. (1878): Die Reptilien und Fische der böhmischen Kreideformation. - Verlag des Verfassers, Prag, [iv] + $44+$ [2] pp., 10 pl.

Gagnaison, C. (2013): Les assemblages de vertébrés dans deux sites paléontologiques du basin miocène de Savigné-sur-Lathan/Noyant-sous-le-Lude : la Guimardière et Pelmer (Maine-et-Loire, France). - Geodiversitas, 35: 67-103. http://dx.doi.org/10.5252/g2013n1a5

Gaudant, J. (1980): Louis Agassiz (1807-1873) fondateur de la paléoichthyologie. - Revue d'Histoire des Sciences, 33: 151-162. http://dx.doi.org/10.3406/rhs.1980.1680

Geinitz, H.-B. (1842): Charakteristik der Schichten und Petrefacten des Sächsisch-böhmischen Kreidegebirges, Drittes Heft, Die sächsisch-bömische Schweiz, die Oberlausitz und das Innere von Böhmen. - Arnoldische Buchhandlung, Dresden and Leipzig, [ii] + 63-116 + xxv pp., pl. 17-24.

Geinitz, H.-B. (1849): Das Quadersandsteingebirge oder Kreidegebirge in Deutschland. - Craz \& Gerlach, Freiberg, iv $+292+[1]$ pp., 12 pls.
Geinitz, H.-B. (1850): Charakteristik der Schichten und Petrefacten des Sächsisch-böhmischen Kreidegebirges, sowie der Versteinerungen von Kieslingswalda. Arnoldische Buchhandlung, Leipzig, xxii $+[\mathrm{iv}]+116+$ xxii + iv +19 pp., 31 pls.

Geinitz, H.-B. (1875): Das Elbthalgebirge in Sachsen. 2. Theil : Der mittlere und obere Quader. VI. Würmer, Krebse, Fische, Reptilien und Pflanzen. - Palaeontographica, 20: 199-245, pl. 37-46.

Giebel, C. G. (1848): Fauna der Vorwelt mit steter Berücksichtigung der lebenden Thiere. Erster Band: Wirbelthiere, Dritte Abtheilung: Fische. - F. A. Brockhaus, Leipzig, xii +467 pp.

Goto, M., Uyeno, T., Yabumoto, Y. (1996): Summary of Mesozoic elasmobranch remains from Japan. - In: Arratia, G., Viohl, G. (eds), Mesozoic fishes - Systematics and Paleoecology, Verlag Dr. Friedrich Pfeil, München, p. 73-82.

Guinot, G., Underwood, C. J., Cappetta, H., Ward, D. J. (2013): Sharks (Elasmobranchii: Euselachii) from the Late Cretaceous of France and the UK. - Journal of Systematic Palaeontology, 11: 589-671. http://dx.doi.org/10.1080/14772019.2013.767286

Hakenberg, M. (1969): Albian and Cenomanian between Małogoszcz and Staniewice, SW border of the Holy Cross Mountains. - Studia Geologica Polonica, 26: $1-126,8$ pls.

Hamm, S. (2008): Systematic, stratigraphic, geographic and paleoecological distribution of the late Cretaceous shark genus Ptychodus within the Western Interior Seaway; Master thesis. - MS, University of Texas, Dallas, USA, xiv +434 pp. (Eugene McDermott Library, University of Texas at Dallas)

Hanzlíková, E. (1972): Carpathian Upper Cretaceous foraminiferida of Moravia (Turonian-Maastrichtian). Rozpravy Ústředního ústavu geologického, 39: 1-160, 40 pls.

Hanzlíková, E., Roth, Z. (1963): Review of the Cretaceous stratigraphy of the Flysch zone in West Carpathians. Geologický sborník, 14: 37-108.

Herman, J. (1977): Les sélaciens des terrains néocrétacés et paléocènes de Belgique et des contrées limitrophes. Elements d'une biostratigraphie inter-continentale. Mémoires pour servir à l'Explication des Cartes géologiques et minières de la Belgique, 15 (1975): 1-401.

International Commission on Zoological Nomenclature (ICZN) (1999): International Code of Zoological Nomenclature. $4^{\text {th }}$ edition. - International Trust for Zoological Nomenclature, London, xxix +306 pp.

Itoigawa, J., Nishimoto, N., Hiroyuki, A. (1977): Cretaceous fossil elasmobranchs from japan (first report). - Bulletin of the Mizunami Fossil Museum, 4: 119-138, pl. 30-34.

Kear, B. P., Ekrt, B., Prokop, J., Georgalis, G. L. (2014): Turonian marine amniotes from the Bohemian Cretaceous Basin, Czech Republic. - Geological Magazine, 151: 183-198. http://dx.doi.org/10.1017/S0016756813000502

Kiprijanoff, V. (1852): Fisch-Ueberreste im Kurskschen eisenhaltigen Sandsteine, zweiter Aufsatz. - Bulletin de la Société Impériale des Naturalistes de Moscou, 25: 483-495, pl. 12-13. 
Knorr, G.W., Walch, J. E. I. (1769): Die Naturgeschichte der Versteinerungen, volume 2, section 2. - Paul Jonathan Felssecker, Nürnberg, [vi] + 303 pp., 131 pls.

Knorr, G. W., Walch, J. E. I. (1775): Recueil de monumens des catastrophes que le globe de la terre a éssuiées contenant des pétrifications dessinées, gravées et enluminées, d'après les originaux, volume 2, section 2. Nuremberg, [vi] + 268 (recte 266) pp., 50 pls.

Krajewski, S., Urbaniak, J. (1964): Znaleziska fauny w północnych Karpatach fliszowych. Cz. I, Wielokomórkowce [The localities with fauna in the northern Flysch Carpathians. Part I, Metazoans]. - Biuletyn, Instytut Geologiczny, 179: 1-236. (in Polish)

Ladwig, J. (2003): Erstnachweis eines Zahnes von Ptychodus latissimus Agassiz 1843 aus dem Geschiebe. - Der Geschiebsammler, 36: 43-46.

Liebus, A. (1902): Über einige Fossilien aus der Karpathischen Kreide. - Beiträge zur Paläontologie und Geologie Österreich-Ungarns und des Orients, 14: 113-130, pl. 6.

Longbottom, A. E., Patterson, C. (1987): Fishes. - In: Smith, A. B. (ed.), Fossils of the Chalk (Field Guides to Fossils, nr. 2), The Palaeontological Association, London, p. 238-265, pl. 54-56.

Małecki, J. (1980): Teeth of fishes of the genus Ptychodus from Cretaceous chalk sediments in the vicinity of Cracow. - Bulletin de l'Académie Polonaise des Sciences, Série des Sciences de la Terre, 28: 51-57.

Malvesy, T., Cappetta, H., Dutheil, D. B., Otero, O., Oudoire, T. (2002): Les collections du Musée d'Histoire Naturelle de Lille. IV. - poissons mésozoïques et cénozoïques (types et figurés). - Annales de la Société Géologique du Nord, série 2, 9: 147-157.

Mantell, G. (1822): The fossils of the South Downs; or illustrations of the geology of Sussex. - Lupton Relfe, London, $x i v+[\mathrm{xv}-\mathrm{xvi}]+328$ pp., 42 pls.

Mantell, G. (1836): A Descriptive catalogue of the objects of geology, natural history, and antiquity (chiefly discovered in Sussex,) in the Museum, attached to the Sussex Scientific and Literary Institution, at Brighton, $4^{\text {th }}$ edition. - Relfe and Fletcher, London, 44 pp.

Marcinowski, R., Radwanski, A. (1983): The MidCretaceous transgression onto the Central Polish Uplands (marginal part of the Central European Basin). Zitteliana, 10: 65-95.

Matějka, A., Roth, Z. (1949): Předběžné poznámky ku geologii moravskoslezských Bezkyd [Preliminary Remarks to the Geology of the Moravo-Silesian Bezkydy]. - Sborník Státního geologiského ústavu Československé republiky, 16(1): 293-328. (in Czech with English summary).

Mendiola, C. (2004): Primera cita espa-ola del género Ptychodus Agassiz 1839 (Chondrichthyes, Euselachii). Revista de la Societat Paleontológica d'Elx, 13: 1-11.

Morton, S. G. (1834): Synopsis of the organic remains of the Cretaceous group of the United States. - Key \& Biddle, Philadelphia, [i]-vi + [7]-88+[1]-[4] + [1]-8 + [1]-[8] pp., 19 pls.

Niedźwiedzki, R., Kalina, M. (2003): Late Cretaceous sharks in the Opole Silesia region (SW Poland). - Geologia Sudetica, 35: 13-24.
Popov, E. V., Lapkin, A. V. (2000): A new shark species of the genus Galeorhinus (Chondrichthyes, Triakidae) from the Cenomanian of the Lower Volga River Basin. Paleontological Journal, 34: 435-438.

Pyrah, B. J. (1979): Catalogue of type and figured fossils in the Yorkshire Museum: Part 4. Pisces, Reptilia, Aves, Mammalia, Plantae. - Proceedings of the Yorkshire Geological Society, 42(3): 415-437.

http://dx.doi.org/10.1144/pygs.42.3.415

Radwanski, A., Marcinowski, R. (1996): Elasmobranch teeth from the mid-Cretaceous sequence of the Mangyshlak Mountains, Western Kazakhstan. - Acta Geologica Polonica, 46: 165-169.

Reuss, A. E. (1844): Geognostische Skizzen aus Böhmen, Zweiter Band. Die Kreidegebilde des westlichen Böhmens, ein monographischen Versuch. Nebst Bemerkung über die Braunkohlenlager jenseits der Elbe und eine Uebersicht der fossilen Fischreste Böhmens. - C. W. Medau \& Comp., Prag, [ii] + vi + 304 pp.

Reuss, A. E. (1845): Die Versteinerungen der böhmischen Kreideformation, Erste Abtheilung. - Schweizerbart'sche Verlagsbuchhandlung und Druckerei, Stuttgart, iv +58 pp., pl. 1-13.

Schlotheim, E. F. von (1822): Nachträge zur Petrefactenkunde. - Becker'schen Buchhandlung, Gotha, xii +100 pp., 21 pls.

Schweizer, C. R. (2004): Bohemian mineralogy in the early $19^{\text {th }}$ century: the Vaterländisches Museum in Böhmen. - In: Winkler Prins, C. F., Donovan, S. K. (eds), VII International Symposium on Cultural Heritage in Geosciences, Mining and Metallurgy: Libraries, Archives, Museums, Leiden (The Netherlands), 19-23 May 2003. Scripta Geologica, Special Issue, 4: 237-248.

Shimada, K., Everhart, M. J. (2003): Ptychodus mammillaris (Elasmobranchii) and Enchodus cf. E. shumardi (Teleostei) from the Fort Hays Limestone Member of the Niobrara Chalk (Upper Cretaceous) in Ellis County, Kansas. - Transactions of the Kansas Academy of Science, 106: 171-176.

http://dx.doi.org/10.1660/0022-8443(2003)106[0171:PM EAEC]2.0.CO;2

Shimada, K., Fielitz, C. (2006): Annoted checklist of fossil fishes from the Smoky Hill Chalk of the Niobrara Chalk (Upper Cretaceous) in Kansas. - In: Lucas, S. G., Sullivan, R. M. (eds), Late Cretaceous vertebrates from the Western Interior. New Mexico Museum of Natural History and Science Bulletin, 35: 193-213.

Shimada, K., Rigsby, C. K., Kim, S. H. (2009): Partial skull of Late Cretaceous durophagous shark, Ptychodus occidentalis (Elasmobranchii: Ptychodontidae), from Nebraska, U.S.A. - Journal of Vertebrate Paleontology, 29: 336-349. http://dx.doi.org/10.1671/039.029.0226

Sirna, G., Dalla Vecchia, F. M., Muscio, G., Piccoli, G. (1994): Catalogue of Paleozoic and Mesozoic vertebrates and vertebrate localities of the Tre Venezie area (North Eastern Italy). - Memorie di Scienze Geologiche, Dipartimento di Geoscienze (Università degli Studi di Padova), 46: 255-281.

Sternberg, K. M. von (1827a): Rede des Präsidenten. Monatschrift der Gesellschaft des vaterländischen Museums in Böhmen, 1(May issue): 59-81, 1 pl. 
Sternberg, K. M. von (1827b): Rede des Präsidenten. Verhandlungen der Gesellschaft des vaterländischen Museums in Böhmen, 5: 12-34, 1 pl.

Sternberg, K. M. von (1827c): Řě Präsidenta hraběte Kašpara Šternberka. - Časopis Společnosti wlastenského museum w Čechách, 1(3): 23-36, 1 pl.

Sternberg, K. M. von (1829a): Rede des Präsidenten in der allgemeinen Sizung des Museums am 30. März 1829. Monatschrift der Gesellschaft des Vaterländischen Museums in Böhmen, 3: 295-306, 376, 1 pl.

Sternberg, K. M. von (1829b): Rede des Präsidenten in der allgemeinen Sizung des Museums am 30. März 1829. Verhandlungen der Gesellschaft des Vaterländischen Museums in Böhmen, 7: 15-26, 33, 1 pl.

Sternberg, K. M. von (1829c): Řě Präsidenta Kašpara hraběte Šternberka na wšeobecném posezení Museum dne 30. března 1829. - Časopis Společnosti wlastenského museum w Čechách, 3(2): 93-104, 1 pl.

Sternberg, K. M. von (1835): Versteinerte Fische im vaterländischen Museum im Prag. - Neues Jahrbuch für Mineralogie, Geognosie, Geologie und Petrefaktenkunde, 1835: 739-740.

Stewart, J. D. (1980): Reevaluation of the phylogenetic position of the Ptychodontidae. - Transactions of the Kansas Academy of Science, 83: 154.

Surdez, M. (1974): Catalogue des archives de Louis Agassiz (1807-1873). - Bulletin de la Société Neuchâteloise des Sciences Naturelles, 97: 5-202.

Trbušek, J. (1999): Upper Cretaceous sharks and rays from the Prokop opencast mine at Březina near Moravská Třebová. - Acta Universitatis Palackianae Olomucensis, Facultas Rerum Naturalium, Geologica, 36: 51-61.

Underwood, C. J., Cumbaa, S. L. (2010): Chondrichthyans from a Cenomanian (Late Cretaceous) bonebed, Saskatchewan, Canada. - Palaeontology, 53: 903-944. http://dx.doi.org/10.1111/j.1475-4983.2010.00969.x

Uyeno, T. (1972): On Cretaceous and Tertiary fish remains from the Hidaka and Yûbari Districts in Hokkaido, Japan. - Memoirs of the National Science Museum, 5: 223-226, pl. 6-7.

Uyeno, T., Sakura, H. (1990): Catalogue of fish fossil specimens. - National Science Museum, Tokyo, vi + $70 \mathrm{pp}$.

Vullo, R., Arnaud, E. (2009): Présence de Ptychodus latissimus Agassiz, 1843 (Elasmobranchii, Hybodontiformes) dans le Crétacé supérieur des Charentes. Annales de la Société des Sciences Naturelles de la Charente-Maritime, 9: 962-966.

Welton, B. J., Farish, R. F. (1993): The collector's guide to fossil sharks and rays from the Cretaceous of Texas. Horton printing co., Dallas, 204 pp.

Wenz, S. (1972): Présence du sélacien Ptychodus (Pt. chappelli) dans le Crétacé supérieur de l'Equateur (Amérique du Sud). - Bulletin du Muséum National d'Histoire Naturelle, Paris, Série 3, Sciences de la Terre, 13(74): 91-94.

Whitham, F. (1991): The stratigraphy of the Upper Cretaceous Ferriby, Welton and Burnham formations north of the Humber, north-east England. - Proceedings of the Yorkshire Geological Society, 48(3): 227-254. http://dx.doi.org/10.1144/pygs.48.3.227
Wiese, F., Čech, S., Ekrt, B., Košt'ák, M., Mazuch, M., Voigt, S. (2004): The Upper Turonian of the Bohemian Cretaceous Basin (Czech Republic) exemplified by the Úpohlavy working quarry: integrated stratigraphy and palaeoceanography of a gateway to the Tethys. Cretaceous Research, 25: 329-352.

http://dx.doi.org/10.1016/j.cretres.2004.01.003

Williamson, T. E., Kirkland, J. I., Lucas, S. G. (1993): Selachians from the Greenhorn cyclothem („Middle“ Cretaceous: Cenomanian-Turonian), Black Mesa, Arizona, and the paleogeographic distribution of Late Cretaceous selachians. - Journal of Paleontology, 67: 447-474.

Wittler, F. (1995): Fische aus dem Turon des Dortmunder Stadtgebietes. - Arbeitskreis Paläontologie Hannover, 23: 41-59.

Woodward, A. S. (1889): Catalogue of the fossil Fishes in the British Museum. Part I. - British Museum (Natural History), London, xlvii + 474 pp., 17 pls.

Woodward, A. S. (1895): Catalogue of the fossil Fishes in the British Museum. Part III. - British Museum (Natural History), London, xxxix +544 pp., 18 pls.

Woodward, A. S. (1912): The fossil fishes of the English Chalk, Part VII. - Monograph of the Palaeontographical Society, 65(320): i-viii + 225-264, pl. 47-54.

Woodward, J. (1729): An attempt towards the natural history of the fossils of England; in a catalogue of the English fossils in the collection of J. Wooward. Tome I. - F. Fayram, London, part 1: xvi $+243+[1]$ pp.; part 2: viii $+115+[1] \mathrm{pp}$.

Yabumoto, Y., Uyeno, T. (1994): Late Mesozoic and Cenozoic fish faunas of Japan. - The Island Arc, 3: 255-269. http://dx.doi.org/10.1111/j.1440-1738.1994.tb00115.x

\section{Appendix 1}

A list of 26 publications by 45 different authors published in the last 50 years, using Ptychodus latissimus AgAssiz, 1835 as valid name to fulfill the requirements of Article 23.9.1.2 of the International Code of Zoological Nomenclature (ICZN 1999):

Antunes and Cappetta 2002, Bendix-Almgreen 1983, Cappetta 2012, Cappetta and Case 1999, Coggi 1964, Diedrich 2013, Ekrt et al. 2004, Goto et al. 1996, Herman 1977, Itoigawa et al. 1977, Ladwig 2003, Longbottom and Patterson 1987, Małecki 1980, Malvesy et al. 2002, Niedźwiedzki and Kalina 2003, Popov and Lapkin 2000, Radwanski and Marcinowski 1996, Shimada and Fielitz 2006, Sirna et al. 1994, Uyeno 1972, Uyeno and Sakura 1990, Vullo and Arnaud 2009, Welton and Farish 1993, Wenz 1972, Wiese et al. 2004, Yabumoto and Uyeno 1994.

\section{Appendix 2}

A list of 33 publications by 60 different authors published in the last 45 years, using Ptychodus mammillaris AGASSIZ, 1835 as valid name to fulfill the requirements of Article 23.9.1.2 of the International Code of Zoological Nomenclature (ICZN 1999): 
Adnet et al. 2008, Albright et al. 2013, Antunes and Cappetta 2002, Becker et al. 2010, Cappetta 2012, Cappetta and Case 1999, Carrillo-Briceño and Lucas 2013, Diedrich 2013, Ekrt et al. 2004, Everhart and Darnell 2004, Gagnaison 2013, Goto et al. 1996, Guinot et al. 2013, Hakenberg 1969, Herman 1977, Itoigawa et al. 1977, Longbottom and Patterson 1987, Małecki 1980, Malvesy et al. 2002,
Marcinowski and Radwanski 1983, Mendiola 2004, Niedźwiedzki and Kalina 2003, Pyrah 1979, Radwanski and Marcinowski 1996, Shimada and Everhart 2003, Sirna et al. 1994, Trbušek 1999, Welton and Farish 1993, Whitham 1991, Wiese et al. 2004, Williamson et al. 1993, Wittler 1995, Yabumoto and Uyeno 1994.

Table 1. Publication dates up to 1843 for selected references to Buffonites Sternberg, 1829 and Ptychodus Agassiz, 1835.

\begin{tabular}{|c|c|c|c|}
\hline Date of publication & Reference & Mentioned species & $\begin{array}{l}\text { Reference to figures published } \\
\text { in other works }\end{array}$ \\
\hline 1829 & Sternberg $(1829 a-c)$ & $\begin{array}{l}\text { Buffonites undulatus nov. gen., nov. sp. } \\
\text { [nomen oblitum] } \\
\text { Buffonites knorrii nov. sp. [nomen oblitum] }\end{array}$ & \\
\hline 1834 & Agassiz (1834a) & $\begin{array}{l}\text { Ptychodus schlotheimii nov. gen., nov. sp. } \\
\text { [nomen oblitum] } \\
\text { Ptychodus mammillaris [nomen nudum] } \\
\text { Ptychodus decurrens [nomen nudum] }\end{array}$ & Sternberg (1827a). \\
\hline January 1835 & $\begin{array}{l}\text { Agassiz (1835a: Feuilleton } \\
\text { additionnel, 54). } \\
\text { idem } \\
\text { idem } \\
\text { idem } \\
\text { idem }\end{array}$ & $\begin{array}{l}\text { Ptychodus latissimus nov. sp. } \\
\text { Ptychodus polygyrus nov. sp. } \\
\text { Ptychodus mammillaris nov. gen., nov. sp. } \\
\text { Ptychodus decurrens [nomen nudum] } \\
\text { Ptychodus altior nov. sp. }\end{array}$ & $\begin{array}{l}\text { Mantell (1822: pl. 32, fig. 19). } \\
\text { Mantell (1822: pl. 32, fig. 23-24). } \\
\text { Mantell (1822: pl. 32, fig. 29, 20, 18, 25). } \\
\text { Mantell (1822: pl. 32, fig. 21, 17, 27). }\end{array}$ \\
\hline October $1836\left({ }^{1}\right)$ & Mantell (1836: 27) & Ptychodus mortoni nov. sp. & Morton (1834: pl. 18, fig. 1-2) \\
\hline September 1837 & $\begin{array}{l}\text { Agassiz (1837: vol. 3, pl. 25a, } \\
\text { fig. 1-7 [non fig. 8]). }\end{array}$ & Ptychodus latissimus Agassiz, 1835 & \\
\hline November 1838 & $\begin{array}{l}\text { Agassiz (1838: vol. 3, pl. 25b, } \\
\text { fig. 11-20; Feuilleton } \\
\text { additionnel, 114). } \\
\text { Agassiz (1838: vol. 3, pl. 25b, } \\
\text { fig. 1-8; Feuilleton } \\
\text { additionnel, 113-114). } \\
\text { Agassiz (1838: vol. 3, pl. 25b, } \\
\text { fig. 9-10, Feuilleton } \\
\text { additionnel, 114). } \\
\text { Agassiz (1838: vol. 3, pl. 25b, } \\
\text { fig. 21-23, Feuilleton } \\
\text { additionnel, 114). } \\
\text { Agassiz (1838: vol. 3, pl. 25b, } \\
\text { fig. 24-26, Feuilleton } \\
\text { additionnel, 114). }\end{array}$ & $\begin{array}{l}\text { Ptychodus mammillaris AGASSIZ, } 1835 \\
\text { Ptychodus decurrens nov. sp. } \\
\text { Ptychodus altior AGASSIZ, } 1835 \\
\text { Ptychodus polygyrus AgASSIZ, } 1835 \\
\text { Ptychodus latissimus AGASSIZ, } 1835\end{array}$ & \\
\hline April 1839 & $\begin{array}{l}\text { Agassiz (1839a: vol. 3, } \\
\text { 151-153). } \\
\text { Agassiz (1839a: vol. 3, } \\
\text { 154-155). } \\
\text { Agassiz (1839a: vol. 3, 155) } \\
\text { Agassiz (1839a: vol. 3, 156, } \\
\text { pl. 25, fig. 4-11). } \\
\text { Agassiz (1839a: vol. 3, pl. 25, } \\
\text { fig. 1-3). }\end{array}$ & $\begin{array}{l}\text { Ptychodus mammillaris AGASSIZ, } 1835 \\
\text { Ptychodus decurrens AGASSIZ, } 1838 \\
\text { Ptychodus altior AGASSIZ, } 1835 \\
\text { Ptychodus polygyrus AGASSIZ, } 1835 \\
\text { Ptychodus mortoni MANTELL, } 1836\end{array}$ & \\
\hline 1843 & $\begin{array}{l}\text { Agassiz (1843: vol. 3, 157). } \\
\text { Agassiz (1843: vol. 3, } \\
\text { 157-158). } \\
\text { Agassiz (1843: vol. 3, 158). }\end{array}$ & $\begin{array}{l}\text { Ptychodus polygyrus AGASSIZ, } 1835 \\
\text { Ptychodus latissimus AGASSIZ, } 1835 \\
\text { Ptychodus mortoni MANTELL, } 1836\end{array}$ & \\
\hline
\end{tabular}

(') (Dean 1998: 78, Everhart 2013). 